\title{
Cauda equina syndrome due to leptomeningeal carcinomatosis: a medical dilemma
}

\author{
Leila Izadi Firouzabadi ㄷ, ${ }^{1}$ Paul Mead, ${ }^{2}$ Jonathan Berry, ${ }^{3}$ Sheharyar Hanif ${ }^{2}$
}

'Dermatology Department, North Cumbria University Hospitals NHS Trust, Carlisle, UK ${ }^{2}$ General Medicine Department, North Cumbria University Hospitals NHS Trust, Whitehaven, UK

${ }^{3}$ Radiology Department, North Cumbria University Hospitals NHS Trust, Carlisle, UK

\section{Correspondence to} Dr Leila Izadi Firouzabadi; lilaizadi@yahoo.com

Accepted 19 January 2020

\section{DESCRIPTION}

We present a case of a 64-year-old woman who was admitted to hospital for investigation of lower back and left leg pain of approximately 7 weeks duration. The pain was originally intermittent and sharp in nature but progressed to a constant severe neuropathic pain despite appropriate analgesia. In addition, her right leg became similarly affected approximately 3 weeks prior to admission. She described numbness of her lower extremities and saddle area. She also had symptoms of urinary retention with occasionally urinary incontinence. Medical history revealed approximately 2 years previously that the patient was diagnosed with a left lung cancer (T3N2M0), histology consistent with a moderately to poorly differentiated adenocarcinoma. Treatment involved left pneumonectomy followed by adjuvant chemotherapy.

On the basis of the clinical features of cauda equina syndrome non-contrast MRI of spine was performed, the results of which were largely unremarkable (figure 1). Her analgesic regime was modified under the supervision of the pain management team with initial good response. Subsequently, she developed blurred vision and confusion. CT scan of the head was insignificant and funduscopy did not show any evidence of papilloedema. Cerebrospinal fluid (CSF) examination showed high protein and lactate with low glucose. CSF cytology revealed large atypical cells and immunohistochemistry was

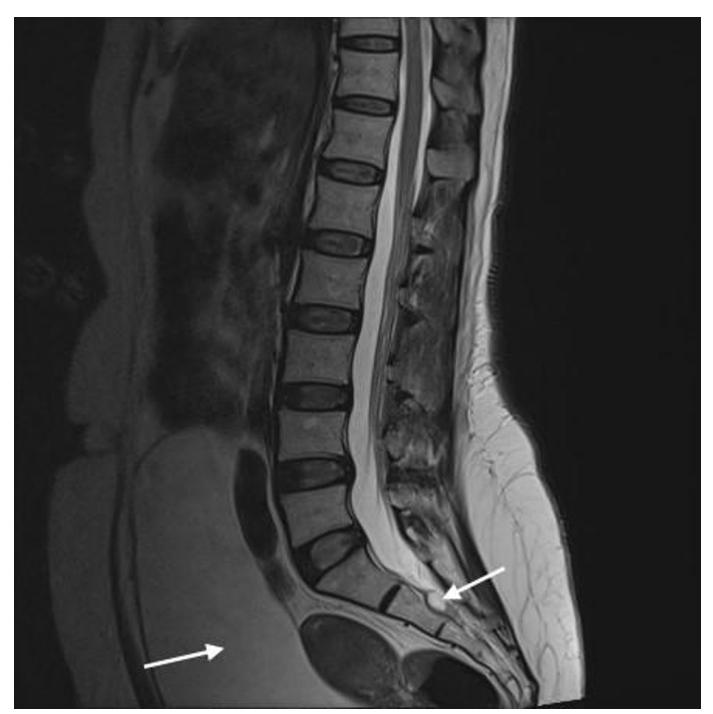

Figure 1 Sagittal T2 weighted image of the lumbar spine demonstrating a significantly distended bladder (left arrow) and a small sacral Tarlov cyst (right arrow) but no leptomeningeal metastases.

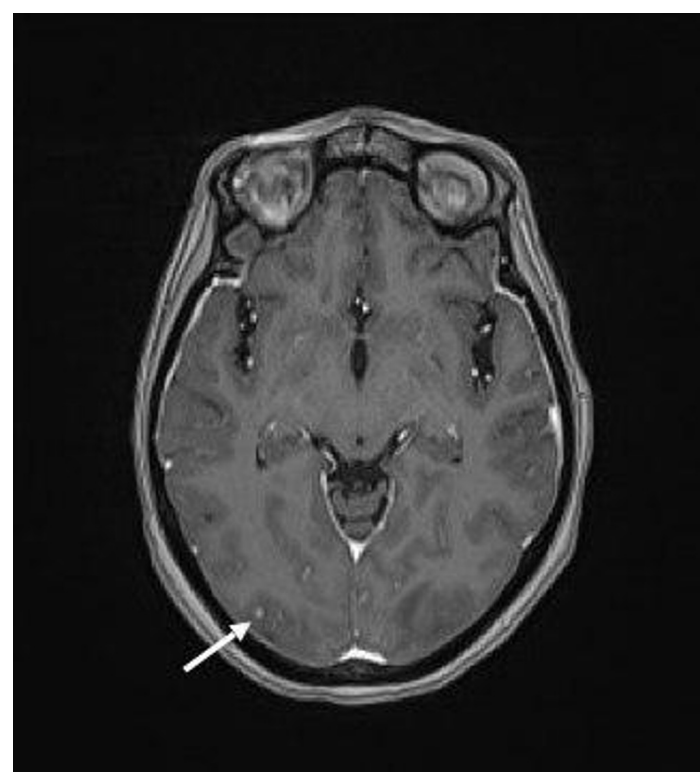

Figure 2 Axial T1 gadolinium contrast enhanced image of the brain demonstrating a discrete nodule (arrow) of meningeal enhancement overlying the right occipital lobe.

suggestive of adenocarcinoma cells. Brain MRI with contrast was reported as consistent with leptomeningeal carcinomatosis (LC) (figure 2). No post contrast spinal MRI was undertaken as a diagnosis of LC was not initially considered. She later developed swallowing difficulties and hearing loss. Unfortunately, she died having been an inpatient for 35 days.

LC is a result of diffuse seeding of the leptomeninges by tumour cells and it affects 1\%-5\% patients with solid tumours. Breast cancer is the most common malignancy which can cause LC followed by lung cancer. ${ }^{1}$ Cauda equina syndrome signs and symptoms include low back pain, unilateral or usually bilateral sciatica, saddle sensory disturbances, bladder and bowel dysfunction and variable lower extremity motor and sensory loss. ${ }^{2}$

Learning points

- There is a strong possibility of leptomeningeal carcinomatosis ( $\mathrm{LC}$ ) in any patient who has a history of cancer and presenting signs and symptoms of cauda equina syndrome.

- The diagnosis of LC cannot be ruled out only on the basis of normal imaging studies.

- The gold standard of LC diagnosis is cerebrospinal fluid examination. 
Although the most common cause of cauda equina syndrome is compression, a diagnosis of LC should be considered in any patient with a history of cancer. ${ }^{3}$ The prognosis of LC is poor and survival without treatment is $4-6$ weeks. An increase in the survival is expectable with early diagnosis and treatment with chemotherapy and/or radiotherapy. ${ }^{1}$

Contributors SH was involved in patient management. PM was involved in patient management and made a revision to the article. LIF designed and drafted work. JB reported the MRI and helped with the images.

Funding The authors have not declared a specific grant for this research from any funding agency in the public, commercial or not-for-profit sectors.

Competing interests None declared.
Patient consent for publication Next of kin consent obtained.

Provenance and peer review Not commissioned; externally peer reviewed.

\section{ORCID iD}

Leila Izadi Firouzabadi http://orcid.org/0000-0001-5385-6273

\section{REFERENCES}

1 Nayar G, Ejikeme T, Chongsathidkiet P, et al. Leptomeningeal disease: current diagnostic and therapeutic strategies. Oncotarget 2017;8:73312-28.

2 Zhou ZN, Canon C, Matrai C, et al. Cauda equina syndrome secondary to leptomeningeal metastases from recurrent primary peritoneal carcinoma. Ecancermedicalscience 2018;12:814.

3 Liu Y, Wang B, Qian Y, et al. Cauda equine syndrome as the primary symptom of leptomeningeal metastases from lung cancer: a case report and review of literature. Onco Targets Ther 2018:11:5009-13.

Copyright 2020 BMJ Publishing Group. All rights reserved. For permission to reuse any of this content visit

https://www.bmj.com/company/products-services/rights-and-licensing/permissions/

BMJ Case Report Fellows may re-use this article for personal use and teaching without any further permission.

Become a Fellow of BMJ Case Reports today and you can:

- Submit as many cases as you like

Enjoy fast sympathetic peer review and rapid publication of accepted articles

- Access all the published articles

- Re-use any of the published material for personal use and teaching without further permission

\section{Customer Service}

If you have any further queries about your subscription, please contact our customer services team on +44 (0) 2071111105 or via email at support@bmj.com.

Visit casereports.bmj.com for more articles like this and to become a Fellow 